\title{
Effect of Inter-sentential vs Intra-sentential Code-Switching: With a Focus on Past Tense
}

\author{
Hanieh Kashi* \\ Department of English Language Qeshm Branch, Islamic Azad University, Qeshm, Iran \\ Corresponding Author: Hanieh Kashi, E-mail: HaniehKashi@gmail.com
}

\section{ARTICLE INFO}

\section{Article history}

Received: December 13, 2017

Accepted: January 25, 2018

Published: March 01, 2018

Volume: 7 Issue: 2

Advance access: February 2018

Conflicts of interest: None Funding: None

\begin{abstract}
The current study aimed at the comparative effect of inter-sentential vs intra-sentential codeswitching on learning past tense. Initially, through non-random convenient sampling, the researcher chose 90 female EFL learners at the elementary level. Next, Key English Test (KET) was administered to the 90 learners and the results were used to select 60 participants for the purpose of this study. The participants were then divided into two groups each consisting of 30 learners. Afterwards, a grammar pretest having 30 items focusing on past simple tense was given to both groups. Following that, the grammatical explanations were provided for the two groups for ten sessions using code-switching. The first experimental group received inter-sentential code switching in line with Reyes's (2004) as a switch between two languages, where a sentence in one of the languages is completed and the next sentence starts with the other language (Reyes, 2004). In the second experimental group, in line with Reyes's (2004), the switching occurred within a sentence. The results of statistical analysis indicated that inter-sentential code-switching proved more effective compared to intra-sentential code-switching on the learning of past tense by EFL learners. Based on the findings of the present study, EFL teachers are encouraged to use inter-sentential code-switching more compared to intra-sentential code-switching when it comes to teaching grammar.
\end{abstract}

Key words: Grammar, Code-switching, First Language, Inter-sentential Code Switching, Intra-sentential Code Switching, Past Tense

\section{INTRODUCTION}

Obviously, code-switching is rather common in bilingual speech and instruction. As a result, many studies have been conducted on the concept of code-switching. In the same vein, $\mathrm{Li}(2000)$ maintains that code-switching is considered as a typical characteristic in speech of bilingual speakers and it should not be considered as an indicator of deficiency. Scholars have put forth various definitions of code switching. For example, Heller (1988) describes code switching as the application of two or more languages during a single communication episode. In the view of Myers-Scotton's (2006), code switching is generally defined as the employment of two language varieties in the same conversation.

Research has indicated that, as a communicative device, code switching depends on the switcher's communicative intents (Adendorff, 1996). Speakers can make use of code switching with the aim of organizing, enhancing and enriching their speech to accomplish their communicative purposes. For instance, as mentioned by Milroy (1987) speakers are likely to use code switching with the aim of expressing solidarity with a particular group. Besides, speakers are able to make use of code switching to bridge a conceptual gap (Gysel, 1992). Generally speaking, it is claimed that code switching can serve as a communication strategy contributing to the continuity of speech so as to compensate for the failure to express certain concepts. Explaining the errors in one' first language can be used as a way to correct the errors, which is called teachers' code switching (CS).

Code Switching is considered as one of the essential concepts in the context of L2 teaching. This technique has been extensively observed, but is researched inadequately. The way in which instructors view their own code switching in the classroom or cope with the L2 learners' code switching directly impacts the instruction methods and pedagogy as well as the learning processes. Belz (2002) defines Codes witching (CS), which is originally borrowed from socio-linguistics, as the application of multiple languages or codes in a single stretch of discourse. Palmer (2009) describes code switching as the individual's capability to use more than one language in a single utterance.

According to Larsen-Freeman (2006), grammar is viewed as the backbone in the case of learning an L2 so much that we cannot delete it from language classroom teaching. Many studies have sought to investigate the effect of grammar learning on learning a new language. For example, Ellis (1985) notes that formal instruction of grammar influences success as well as the acquisition of a new language. In the 
same vein, Ellis (1985) attaches great importance to learning a new language with a view of grammar learning. However, he reiterates that teachers need to adopt an effective method of teaching when it comes to grammar teaching. Purpura (2004) asserts that learning grammar plays an essential role in L2 learning. It seems inevitable for L2 learners to make errors while learning a language in general and the grammar, in particular. Errors as well as the contribution they make to L2 learning have been a controversial issue among different schools of thoughts (Liu, 2008).

Despite the arguments over the efficacy of error correction and feedback (Carroll \& Swain, 1993; Liu, 2008), the main issue is whether the errors should be corrected and who should correct them as both peers or teachers can give feedbacks. In the case of language professions, there is controversy over the role L1 (mother tongue) can potentially play in the quality of EFL learning and teaching along with using translation as a language learning/teaching resource. When it comes to grammar teaching and learning, the errors and how they should be treated are the first challenges popping up in mind.

The purpose of this study was to find out whether or not inter-sentential code-switching has any different effect from intra-sentential code-switching on learning past tense by language learners. Indeed, research on code-switching in the EFL context of Iran is scant and more attention is paid to research on affective factors such as motivation or other linguistic features of language.

\section{Literature Review}

Code switching was defined by Myers-Scotton (2009) as a kind of language which is in turn made of two languages. The new language can have any level, ranging from a word to a clause. This issue has attracted attention in recent years so much that many studies have been conducted in America, Europe, Africa, Asia and the Middle East on code-switching. Various perspectives have been taken into account in research on language change or code switching, i.e. general linguistics, sociolinguistics and psycholinguistics. In the context of the sociolinguistics, many of the models have been proposed to account for conversational choices (e.g. The notion of contextualization cues put forth by Gumperz (1982) and Myers-Scotton's (1983) Markedness Model).

One of the long-standing challenges has to do with the diversity of code-switching patterns, making it hard for any economical and global syntactic account ((Reyes, 2004). Those who are familiar with multiple languages often tend to alternate languages between or even within sentences, especially at the presence of other bilinguals (Scotton \& Ury, 1977). There is general consensus that such code switching can result cognitive costs, including a reduction in comprehension or production when stimuli are concerned with mixed languages, in particular, when the changes in input language occurs unpredictably (Reyes, 2004).

Auer (1998) refers to the circumstances where the juxtaposition of two codes is interpreted as a locally meaningful event by the participants. The researchers have also examined the relationship between language proficiency level and code switching. For example, given the learners' code switching, it should be noted that the kind of code switching used by learners correlates with their level of proficiency in L2 (Reyes, 2004). Reyes (2004) describes inter-sentential switching as a switch between two languages. In this procedure, a sentence is uttered in one language while the next one is uttered in another language. According to Auer (1998), intra-Sentential Switching involves a switch the individual makes from one language into another language inside a sentence.

Moodley (2007) conducted a study in which he investigated the use of code switching by L2 learners in multilingual classrooms through classroom tasks and reported that code switching can have positive effect on language learning. Myers-Scotton (1998) investigated code switching, indicating that this strategy is employed by L2 learners to express friendliness or to protect the listener's self-image. Some scholars (e.g. Burden, 2001) assert that code switching is helpful in English language instruction and learning. Other researchers (e.g. Skiba, 1997) view code switching as a chance for the development of language since it facilitates the effective transmission of information from one individual (sender) to another. In their study, Tien and Liu (2006) concluded that low proficiency learners viewed code-switching in their L2 classes as a useful technique in comprehension.

Simin, Teimouri, Kasmaee, and Rezaei (2005) examined the impact of code-switching on Iranian L2 learners' material learning and also their attitudes towards this linguistic phenomenon. To this end, the participants' notes, taken from the teachers' speech, were carefully studied. This was followed by the qualitative analysis of the written notes with a focus on code-switching. Then, the researchers distributed the questionnaire among the students with the aim of investigating their attitudes. Based on the results of this study, code switching was found to be very helpful in learning, helping the learners to recall better for their exams.

Mori (2004) conducted an investigation in a Japanese class, shedding light on the patterns of code switching in English as a Foreign Language (EFL) classes. Hancock (1997) came to the conclusion that there is no dichotomy between L1 and L2 use in a L2 classroom is not justifiable as code switching is considered as a natural outcome of bilingualism. In accordance with the results of her study, Mori (2004) concluded that the dominant target-language use policy in L2 classrooms need to be revisited and that code switching must be viewed as a helpful teaching and learning strategy.

The study conducted by Badrul Hisham and Kamaruzaman (2009) revealed a correlation between instructors' code-switching and learners' learning given the learners' perceptions of the instructors' code switching in L2 classrooms. Their study indicated that L2 learners viewed code switching as an effective tool because of its multiple functions. The results showed important relationships between instructors' code-switching and L2 learners' affective support and learners' learning efficacy.

In their investigation, Jamshidi and Navehebrahim (2013) examined the effectiveness of the employment of mother tongue in EFL classrooms. Participants in this study were 
divided in beginning, advanced and intermediate groups, with Persian as their native language. All the participants responded to a questionnaire to tap their ideas on the effectiveness of using their mother tongue. Based on the results, the employment of first language by instructors or learners improved the impact of input. The results indicated that the participants who used Persian had been provided with more opportunities to improve their skills.

In their study, Rahimi and Jafari (2011) examined the kinds and functions of code switching as well as gender preferences. The sample of this study consisted of four classes whole performances were observed and audio-recorded. The final results revealed that instructors resorted to code-switching more frequently while they sought to give Persian equivalents of English words and expressions. The study showed that the employment of inter-sentential code-switching was more common. Moreover, code-switching was found to be more frequent at the time when the participants performed the assigned tasks. The results showed that male participants switched while they tried to produce humorous utterances. In contrast, female participants switched more frequently while they tried to give L1 equivalents. Based on the results of the attitude questionnaire, most of the participants believed that students and teachers must not apply Persian so frequently even though it improved their interactions.

AjmalGulzar, Farooq, and Muhammad Umer (2013) probed the different inter-sentential patterns of code-switching used by the L2 learners. The study was a gender based investigation conducted on EFL teachers. The study tried to find which group of teachers male or female resorted to inter-sentential switching more frequently in their discussion. The researchers recorded some sessions in the context of university. The results showed that all the male and female instructors switched code facing shortages with respect to both linguistic resources and verbal genres.

Aiming to make a comparison between intra-sentential switching and inter-sentential switching, Kebeya (2013) examined Inter- and Intra-Sentential Switching. The study sought to compare three kinds of Kenyas local languages Luo/Luyia and Luo/Gusii to shed light on potential code-switching patterns. The results indicated that both intra and inter-sentential switching were dominant in interactions of those two languages. It was observed that some issues influencing intra-sentential switching unlike the others impacted intersentential switching. Consequnelty, they came to the conclusion that it is very difficult an even impossible to compare inter and intrasentential switching.

Momenian and Ghafar Samar (2011) carried out an investigation on the functions of code-switching. They focused on advance and elementary instructors and learners' functions and patterns of code-switching among Iranian EFL learners. In their study, they employed their first language in classroom unlike the principles of traditional teaching. To this end, sixty learners and thirty teachers were chosen to respond to two sets of questionnaire; one for learners the other for teachers. They had to complete the questionnaires on the basis of what they recalled from their classes. Findings indicated that elementary teachers and learners made more frequent use of code-switching compared to the advanced group.

It is evident that grammar plays an important role in L2 learning. Grammar is closely associated with grammatical accuracy. According to Skehan, (1996) effective communication grammatical accuracy should be considered as an essential goal of an L2 instruction. Accurate use of grammar improves the quality of communication, facilitating better interaction and negotiation (Nassaji, 2000). Therefore, instructors need to pay close attention to accuracy by providing L2 learners with needed error correction. As for grammar as an important part of language, a way thereby EFL learners' grammatical accuracy is likely to improve is how feedback is provided. The use of mother tongue or codes switching is one of the ways to provide feedback. Considering the essential role of grammar in EFL learning and the prominence of grammatical accuracy as well as the impact of code switching on grammar learning, this investigation seeks to compare the impact of inter-sentential vs. intra-sentential code-switching on learning past tense.

\section{Research Question}

Q: Is there any significant difference between the effects of intra-sentential and inter-sentential code-switching on learning past tense?

\section{METHODOLOGY}

\section{Participants}

The initial participants of the current study were 90 female elementary EFL students in Safir language institute in Tehran who were selected through convenient sampling method. The researcher explained the aim of the study to several classes and ultimately won the approval of 90 learners to participate in the study. The participants were within the age range of 17 to 32 and all spoke Persian as their mother tongue.

\section{Instruments}

Two instruments were used in the current study. A Key English Test (KET) and a grammar pretest and posttest. The KET was given to the 90 learners and based on descriptive statistics 60 were selected. This test is a test developed by Cambridge ESOL and assesses all the four language skills i.e. speaking, reading, writing and listening. The grammar pretest and posttest was developed by the researcher and it consisted of 30 items. The test was piloted on 30 participants having similar characteristics to the main participants and Cronbach's Alpha was run on the results. The Cronbach's alpha yielded a reliability index of.78 which is considered acceptable.

\section{Procedure}

Initially, through non-random convenient sampling, the researcher chose 90 female EFL learners at the elementary 
level. Next, Le English Test (KET) was administered to the 90 learners and the results were used to select 60 participants for the purpose of this study. To select the target participants, the scores of KET were analyzed through descriptive statistics and 60 learners whose scores will fell between $+/$ - one standard deviation of the mean were selected as the participants of the study.

The participants were then divided into two groups each consisting of 30 learners. Afterwards, a grammar pretest having 30 items focusing on past simple tense was given to both groups to make sure that they were not significantly different in terms of grammar knowledge of past tense prior to the treatment. Having assured that the two groups were not significantly different in terms of overall language proficiency and knowledge of past tense, the treatment began.

To this aim, the researcher started teaching the grammatical points based on the syllabus of the institute via inter-sentential and intra-sentential code-switching. The first experimental group received inter-sentential code switching in line with Reyes's (2004) as a switch between two languages, where a sentence in one of the languages is completed and the next sentence starts with the other language (Reyes, 2004). Therefore, in this group, the grammatical explanations were provided to the learners through the use of Persian so that one sentence of the explanation was completely in Persian and the other sentence utterly in English.

In the second experimental group, in line with Reyes's (2004), the switching occurred within a sentence. To this aim, the grammatical explanations were provided to the learners through the use of Persian within the sentences so that half of the explanation in each sentence was in English and the other half in Persian.

The whole period of treatment was ten sessions. Upon finishing the treatment, the researcher gave the grammar posttest to the two groups the results of which were used to address the research question.

\section{RESULTS AND DISCUSSION}

In the first place the reliability of the grammar test was measured as this test was the one used for homogenizing the participants in terms of grammar knowledge before and after the treatment. The reliability of this test was estimated using the internal consistency measure of Cronbach's Alpha. Table 1 shows the Cronbach's Alpha of the grammar test administered to a pilot sample of 30 EFL learners.
The results of reliability analysis in the pilot study indicated that the test had a reliability index above 0.78 which is an acceptable level of reliability.

\section{PRETEST RESULTS}

The grammar pretest scores of the two groups were compared utilizing independent samples t-test. Table 2 displays the descriptive statistics.

As seen in Table 2, the inter-sentential group had a mean score of $18.80(\mathrm{SD}=3.7)$ and the intra-sentential group had a mean score of 19.20 ( $\mathrm{SD}=3.25)$. Though the two groups had similar mean scores, an independent samples t-test was run on the scores to further make sure they were not significantly different from each other or in other words they were homogeneous in terms of grammar. Table 3 presents the independent samples t-test results.

According to the results of Levene's test of equality of variances (see Table 3), both groups had equal variances in grammar pretest scores $(\mathrm{p}>0.05)$ based on which the researcher assumed equal variances for the two groups. Based on t-test results, the significant level was greater than the confidence interval of 0.05 , indicating no significant differences between the two groups in terms of grammar knowledge prior to the min study.

\section{Addressing the Research Question}

The research question of the current study sought to investigate any statistically significant difference in the effects of intra-sentential and inter-sentential code-switching on learning past tense.In order to examine this question, it was needed to compare the groups' grammar posttest scores. Table 4 shows the descriptive statistics of the two groups on the grammar posttest.

After scoring the papers, it was found that the inter-sentential group had a mean score of $24.00(\mathrm{SD}=4.51)$ and the intra-sentential group had a mean score of $19.16(\mathrm{SD}=5.43)$. It was not possible to judge on the significance of such mean difference between the two groups; therefore, an independent samples t-test was run on the posttest scores of the two groups. Table 5 shows the results of the independent samples t-test on the scores of the groups.

According to the results of Levene's test of equality of variances, both groups had equal variances in grammar scores $(p>0.05)$, based on which the researcher assumed equal variances for the two groups. Results of t-test showed

Table 1. Reliability analysis of Grammar test using Cronbach's alpha

\begin{tabular}{cccccc}
\hline & N & Mean & Standard deviation & Alpha & Number of items \\
\hline Grammar test & 30 & 19.1333 & 3.63634 & 0.78 & 30 \\
\hline
\end{tabular}

Table 2. Descriptive statistics of experimental and control groups on Nelson test

\begin{tabular}{lllccr}
\hline & Group & N & Mean & Standard deviation & Standard error mean \\
\hline \multirow{2}{*}{ Nelson } & Inter-sentential & 30 & 18.80 & 3.72 & 0.68 \\
& Intra-sentential & 30 & 19.20 & 3.25 & 0.59 \\
\hline
\end{tabular}


Table 3. Independent samples t-test between the two groups pretest grammar scores

\begin{tabular}{lccccr}
\hline & \multicolumn{1}{c}{$\begin{array}{c}\text { Levene's test for } \\
\text { equality of variances }\end{array}$} & & \multicolumn{3}{c}{ t-test for equality of means } \\
\cline { 2 - 5 } & $\mathbf{F}$ & & d & Sig. (2-tailed) \\
\hline Equal Nelson variances assumed & 1.46 & -0.44 & 58 & 0.65 \\
Equal variances not assumed & & -0.44 & 56.95 & 0.66 \\
\hline
\end{tabular}

Table 4. Descriptive statistics of the two groups on Grammar posttest

\begin{tabular}{lllccr}
\hline & Group & N & Mean & Standard deviation & Standard error mean \\
\hline \multirow{2}{*}{ Grammar } & Inter-sentential & 30 & 24.00 & 4.51 & 0.82 \\
& Intra-sentential & 30 & 19.16 & 5.43 & 0.99 \\
\hline
\end{tabular}

Table 5. Results of the independent samples t-test on the Grammar posttest scores

\begin{tabular}{|c|c|c|c|c|c|c|}
\hline & \multicolumn{2}{|c|}{$\begin{array}{c}\text { Levene's test for equality } \\
\text { of variances }\end{array}$} & \multicolumn{4}{|c|}{ t-test for equality of means } \\
\hline & $\mathbf{F}$ & Sig. & $\mathbf{t}$ & df & Sig. (2-tailed) & Mean difference \\
\hline Equal variances assumed & 0.02 & 0.86 & 3.74 & 58 & 0.00 & 4.83 \\
\hline Equal variances not assumed & & & 3.74 & 56.07 & 0.00 & 4.83 \\
\hline
\end{tabular}

that the significant level was smaller than the confidence interval of 0.05 , indicating a significant difference between the two groups in terms of grammar posttest scores. Therefore, it was concluded that there was a significant difference between the intra-sentential and inter-sentential groups and due to the fact that the inter-sentential group had higher mean score on the posttest, it was inferred that inter-sentential code-switching proved more effective on the learning of past tense by EFL learners.

\section{CONCLUSION/DISCUSSION}

This study investigated the effects of inter-sentential vs. intra sentential code switching on leaning past tense by Iranian EFL learners. The results of the study gained through t-test revealed that a significant difference exists between learning past tense when inter-sentential and intra-sentential code switching are used. In addition it was found that inter-sentential code-switching has more effect on learning past tense.

The findings of this study are in line with the study conducted by Heredia and Brown (2005) who concluded that code switching is a useful tool for learners to comprehend the materials better. In addition, the findings of the investigation are consistent with some previous studies (Badrul, Hisham \& Kamaruzaman, 2009; Burden, 2001; Simin, Teimouri, Kasmaee \& Rezaei, 2005; Skiba, 1997) who confirmed the efficacy of the employment of code-switching on EFL learners' grammar learning.

The findings of this study run counter to those of Kebeya (2013) who concluded that no difference was found between the impacts of inter and intra-sentential switching since the findings of the present study showed that the learners in intra-sentential group had better performance than those in inter-sentential switching one. The results of this investigation also are inconsistent with the findings of Novianti (2003) who claimed that intra-sentential switching is a better kind of code-switching with respect to the instruction of grammar.The findings of this investigation also run counter to those of Simon and Thomas (2001) who concluded that the employment of code-switching in classrooms do not influence the students' learning because of the fact that applying code-switching in the classroom discourages learners from speaking in the target language.

As for the positive impact of feedback through code-switching on grammatical accuracy, the following studies can be mentioned: Chandler (2003), Ellis (2001), Ferris and Helt (2000) Fotos (2002), Norris and Ortegga (2000). In a meta-analysis study conducted by Norris and Ortegga (2000), there was an emphasis on the direct intervention in the case of the grammatical aspect of language, with corrective feedback through code switching as an important means to accomplish it. Treglia (2009) notes that L2 learnersneed to receive corrective feedback on their writing. It is also worth noting that with respect to the impact of corrective feedback on grammatical accuracy, the majority of empirical studies are in favor of it (Ferris, 2004).

Beside the important role of feedback in language learning such as grammar, the employment of the first language mediatedthrough code switching can be useful in the L2 learning. In an investigation, Banos (2009) concluded that L1 facilitates L2 learning. He reiterated that the application of mother tongue is permissible as far as it benefits the L2 learners. In his study, Cook (2001) explained about different positions adopted by scholars and educators to upheld theemployment ofL1 in L2 teaching and learning. Cook takes issue with the common argument that learners should acquire second language in the same way they have acquired their L1. To corroborate this claim, he notes that in the case of L2 learning, the individuals are cognitively and emotionally more mature than L1 learners. 
Cook (2001) has put forth several areaswhere L2teachers can incorporate L1 into L2 learning. Moreover, he maintains that L2 teachers can use their own first language to teach explicit grammatical rules and understand these rules more effectively. He also acknowledges that the use of L1 can shorten the time and efforts teachers need to teach the rules and words. Atkinson, (1987, as cited in Bouangeune, 2009) claims that using L1 might be useful in teaching grammar. Moreover, he maintains that translation is favored by students, and it assists learners to express feelings concerning the points they may not understand very well.

\section{REFERENCES}

Auer, p. (1998). Code-switching in conversation: Language, interaction and identity. New York \& London: Routledge.

Badrul Hisham, A \& Kamaruzaman, J. (2009). Teachers' Code-Switching in Classroom Instructions for Low English Proficient Learners. English Language Teaching Journal, 2, (2), 221-231.

Banos, M. O. (2009). Mother tongue in the L2 classroom: A positive or Negative tool? Revista Lindaraja, 21(4) 421-428.

Belz, J. A. (2002). The myth of the deficient communicator. Language Teaching Research, 61(1), 59-82.

Bouangeune, S. (2009). Using L1 in teaching vocabulary to low English proficiency level students: A case study at the University of Laos. English Language Teaching Journal, 2(3), 186-193.

Burden, P. (2001). When do native English speakers and Japanese college students disagree about the use of Japanese in the English conversation classroom? The Language Teacher, April 2001. Retrieved from: http:// www.jaltpublications.org/tlt/articles/2001/04/burden.

Carroll, S., \& Swain, M. (1993). Explicit and implicit negative feedback: An empirical study of the learning of linguistic generalizations. Studies in Second Language Acquisition, 15(3), 357-386.

Chandler, J. (2003). The efficacy of various kinds of error feedback for improvement in the accuracy and fluency of L2 student writing. Journal of Second Language Writing, 12(3), 267-296.

Cook, V. (2001). Using the first language in the classroom. The Canadian Modern Language Review, 57(3), 402-423.

Ellis, R. (1985). Understanding second language acquisition. Oxford: Oxford University Press.

Ellis, N. C. (2001). Memory for language. In P. Robinson (Ed.), Cognition and second language instruction (pp. 33-68). Cambridge: Cambridge University Press.

Ferris, D., \& Helt, M. (2000, March). Was Truscott right? New evidence on the effects of error correction in L2 writing classes. Paper presented at AAAL Conference, Vancouver, BC.

Fotos, S. (2002). Structure-based interactive tasks for the EFL grammar learner. In E. Hinkel\& S. Fotos (Eds.), new perspectives on grammar teaching in second language classrooms (pp. 135-154). Mahwah, NJ: Erlbaum.
Gumperz, J. (1982). Discourse strategies. Cambridge: Cambridge University Press.

Gysels, M. (1992). French in urban Lubumbashi Swahili: Code switching, borrowing, or both. Journal of Multilingual and Multicultural Development, 13 (1), 41-55.

Hancock, C.R. (1994). Alternative Assessment and Second Language Study: What and Why? ERIC Clearinghouse on Languages and Linguistics, Washington, DC: Center for Applied Linguistics.

Jamshidi, A \& Navehebrahim, N. (2013). Learners Use of Code Switching in the English as a Foreign Language Classroom. Australian Journal of Basic and Applied Sciences, 7(1), 123-132.

Kebeya, H.)2013(. Inter- and Intra-Sentential Switching: Are they really Comparable? 5. Nairobi, Kenya: Kenyatta University.

Larsen-Freeman, D. (2006). The emergence of complexity, fluency, and accuracy in the oral and written production of five Chinese learners of English. Applied Linguistics, 27(4), 590-619.

Liu, H. J. (2008). A study of the interrelationship between listening strategy use, listening proficiency levels, and learning style. RARECLS, 5(1), 84-104.

Milroy, L. (1987). Observing and analysing natural language. Oxford: Blackwell.

Momenian, M \& Ghafar Samar, R. (2011). Functions of code-switching among Iranian advanced and elementary teachers and students. Vol. 6(13), pp. 769-777. Iran: Tehran, Tarbiat Modares University.

Moodley, V. (2007). Code switching in the multilingual English first language classroom. International Journal of Bilingual Education and Bilingualism, 10, 707-722.

Mori, S. (2004). Significant motivational predictors of the amount of reading by EFL learners in Japan. Regional Language Centre Journal, 35(1), 63-81.

Myers-Scotton, C. (1988). Self-enhancing code switching as interactional power. Language and Communication, 8(3): $199-211$.

Myers-Scotton, C., (2006). Multiple voices: an introduction to Bilingualism, Blackwell publishing.

Nassaji, H. (2000). Towards Integrating Form-Focused Instruction and Communicative Interaction in the Second Language Classroom: Some Pedagogical Possibilities. The Modern Language Journal, 84(3), 241-250.

Norris, J., \& Ortega, L. (2000). Effectiveness of L2 instruction: A research synthesis and quantitative meta-analysis. Language Learning, 50(5), 417-528.

Novianti, W. (2003). The Use of Code Switching in Twitter. (A Case Study in English Education Department) 2. 1-10

Palmer, D. K. (2009). Code-switching and symbolic power in a second-grade Two-way classroom: A teacher's motivation system gone awry. Bilingual Research Journal, 32(1), 42-59.

Purpura, J. (2004). Assessing grammar. Cambridge: Cambridge University Press.

Rahimi, A., \& Jafari, Z. (2011). Iranian students' attitudes towards the facilitative and debilitative role of code-switching; types and moments of code-switching at EFL classroom. 
The Buckingham Journal of Language and Linguistics, Vol 4. 15-28.

Reyes, I. (2004). Functions of code switching in school children' conversations. Bilingual Research Journal. 28(1), 77-98.

Scotton, C.M., \& Ury, W. (1977). Bilingual strategies: The Social functions of code switching Linguistics, 193, 5-20.

Simin, S., Teimouri, F., Kasmaee, H., \& Rezaei, S. (2005). The role and the effects of code-switching in material learning. The first national conference on research in teaching English, translation, and linguistics.

Skehan, P. (1996). A framework for the implementation of task-based instruction. Applied Linguistics, 17(1), 38-62.

Skiba, R. (1997). Code switching as a countenance of language interference. The Internet TESL Journal, 10(8). Retrieved from http://iteslj.org/Articles/Skiba-CodeSwitching.html

Spada, N., (1997), Form-Focused Instruction and Second Language Acquisition: A Review of Classroom and Laboratory Research Language Teaching, 30, 73.

Tien, C and Liu, K. (2006). Code-switching in two EFL classes in Taiwan. In Azirah Hashim \& Norizah Hassan. (Eds). English in Southeast Asia: prospects, perspectives and possibilities. Kuala Lumpur: Universiti Malaya Press. 